\title{
Bioplastic Degradation Potential of Microorganisms Isolated from the Soil
}

\author{
Email address: \\ cnariole@yahoo.com (C. N. Ariole) \\ ${ }^{*}$ Corresponding author
}

Caroline Nchedo Ariole*, Okorite George-West

Department of Microbiology, Faculty of Science, University of Port Harcourt, Port Harcourt, Nigeria

\section{To cite this article:}

Caroline Nchedo Ariole, Okorite George-West. Bioplastic Degradation Potential of Microorganisms Isolated from the Soil. American Journal of Chemical and Biochemical Engineering. Vol. 4, No. 1, 2020, pp. 1-7. doi: 10.11648/j.ajcbe.20200401.11

Received: January 3, 2020; Accepted: January 10, 2020; Published: February 14, 2020

\begin{abstract}
Plastic disposal is among the utmost problems threatening the environment at present, as enormous quantities of synthetic plastics are non-degradable. A constant exploration for bioplastic degraders is needed due to increasing demands for sustainable waste treatments. Bioplastic (Polycaprolactone) degradation potential of microorganisms isolated from soil was assessed. Soil sample was collected from a plastic dump site in Trans-Amadi, Port Harcourt, Nigeria. Isolation of Polycaprolactone (PCL) degrading bacteria and fungi were carried out via enrichment procedure and clear zone technique. Morphological, biochemical and molecular characteristics were used for strain identification of isolates. The optimal conditions for PCL degradation by bacterial and fungal strains were evaluated by growing the isolates at different temperatures $\left(25,30,35\right.$ and $\left.40^{\circ} \mathrm{C}\right)$, medium $\mathrm{pH}$ (ranging from $\mathrm{pH} 4$ to 8$)$ and salinities $(5,10,15$ and $20 \mathrm{ppt}$.) for 15 days. PCL residual weight in the culture was measured and used for PCL degradation assessment. Three PCL degrading bacterial strains (Bacillus megaterium, Alcaligenes aquatilis and Shewanella haliotis) and one fungal strain (Filobasidium uniguttalatum) were isolated. PCL maximum degradation rate of 59\%, 56\% and 53\% respectively for bacterial strains and $62 \%$ for fungal strain were observed at $30^{\circ} \mathrm{C}$. PCL maximum degradation rate of $63 \%$ for Filobasidium uniguttalatum were observed at pH 5 while the maximum degradation rate of $60 \%$ for Bacillus megaterium, 54\% for Alcaligenes aquatilis and $57 \%$ for Shewanella haliotis were observed at $\mathrm{pH}$ 7. PCL maximum degradation rate of $58 \%$ for Bacillus megaterium, $55 \%$ for Alcaligenes aquatilis, $52 \%$ for Shewanella haliotis and $62 \%$ for Filobasidium uniguttalatum were observed at salinity of 5 ppt. It is concluded that the potential of the isolated indigenous microbial strains to degrade PCL qualifies them for use as compost cultures in waste treatment of bioplastic.
\end{abstract}

Keywords: Bioplastic, Polycaprolactone, Biodegradation, Synthetic Plastics, Bacteria, Fungi

\section{Introduction}

Biodegradable plastics are receiving major consideration as alternative to synthetic plastics whose increase as waste in the environment adversely affects the ecological unit $[1,2]$. Hence plastic producers constantly optimize biodegradable products appropriate for domestic, industrial and agricultural purposes [3, 4]. But, in Nigeria, environmental pollution by plastic waste is on the increase and yet plastic manufacturers are yet to start production of biodegradable products. Polycaprolactone (PCL) is a petroleum-based polymer that can be degraded by microbes [5]. Nevertheless, accomplishing degradation in natural soils remains vague. Waste volume reduction is achieved when suitable microorganisms are applied during disposal of bioplastics leading to increased space availability in landfills [6]. Hence, inoculation with required microorganisms is essential for bioplastic degradation. The bioplastic degraders should be sourced for to lessen the buildup of plastic waste in the environs. Such microorganisms may possibly be added for enhanced biodegradation. Alcaligenes faecalis and Paecilomyces lilacinus were revealed to degrade PCL [7, 8]. PCL degradation by thermophilic actinomycetes [9] and Brevundimonas sp. strain MRL- ANI from soil [10] have been reported. Numerous anaerobic and aerobic polymerdegrading microbes have been isolated from seawater, soil and activated sludge [5]. There is no report of PCL degrading microbes inhabiting the Niger Delta environment. 
Isolation and selection of indigenous strains able to degrade bioplastic to meet the precise requirement in Nigeria is needed. In this study, therefore, we assessed the polycaprolactone (PCL) degradation potential of bacteria and fungi isolated from a plastic dumpsite situated at Trans Amadi, Port Harcourt, Nigeria.

\section{Materials and Methods}

\subsection{Sample Collection}

Soil sample was collected from a plastic dumpsite at Trans Amadi Industrial Layout, Port Harcourt, Nigeria with coordinates N $4.817146^{\circ} \mathrm{E} 7.056100$ (Figure 1).

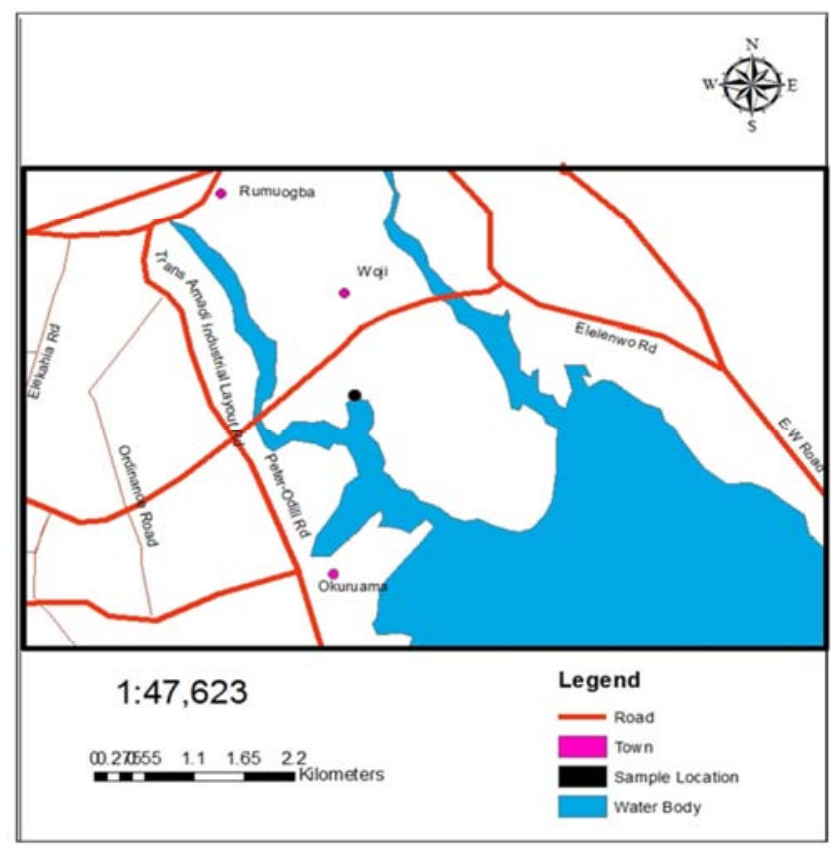

Figure 1. Sample collection site.

\subsection{Source of Bioplastic}

Bioplastic (Poly-caprolactone pellets) was purchased from Sigma Aldrich USA, with average molecular weight 45,000, melting temperature of $60^{\circ} \mathrm{C}$ and Pcode 1002537759 .

\subsection{Enrichment and Isolation of Polycaprolactone- Degrading Bacterial and Fungal Strains}

The polycaprolactone (PCL)-degrading bacteria and fungi were isolated via enrichment culture method and clear zone technique. Amodified mineral salt medium [11] containing ( $\mathrm{g} / \mathrm{L}$ of distilled water): $\mathrm{KH}_{2} \mathrm{PO}_{4} 0.2, \mathrm{~K}_{2} \mathrm{HPO}_{4}$ $0.8, \mathrm{MgSO}_{4} 0.1,\left(\mathrm{NH}_{4}\right)_{2} \mathrm{SO}_{4} 0.4, \mathrm{CaCl}_{2} \quad 0.4, \mathrm{MnSO}_{4} 0.01$ and $\mathrm{FeSO}_{4} 0.02$ was employed. The final $\mathrm{pH}$ was adjusted to 4.5 for fungi and 7.2 for bacteria. The media were autoclaved at $121^{\circ} \mathrm{C}$ for $15 \mathrm{~min}$. Then, $10 \mathrm{~g}$ of soil sample per $100 \mathrm{ml}$ of medium augmented with $1 \mathrm{~g} / \mathrm{L}$ of PCL as the only source of carbon in a $250 \mathrm{ml}$ Erlenmeyer flask was incubated for 7 days at $30^{\circ} \mathrm{C}$. The enrichment technique was done using diverse concentrations $(1,2$ and $5 \mathrm{~g} / \mathrm{L})$ of polycaprolactone in the media. The bacteria and fungi present in the enhancement cultures were isolated on plates of mineral salt agar (pH 7.2 and 4.5 for bacteria and fungi respectively) augmented with $5 \mathrm{~g} / \mathrm{L}$ polycaprolactone via spread plate method.

Isolates with clear zones were selected and streaked again and again on plates of nutrient agar (for bacteria) and acidified potato dextrose agar (for fungi) until pure. Morphological and biochemical characteristics [12] as well as molecular method were used for identification of purified bacterial isolates. The fungal strain was identified based on morphological characteristics [13] and phylogenetic analysis [14].

\subsection{Molecular Characterization of the Microbial Isolates}

\subsubsection{Bacterial Genomic DNA Extraction}

Five millilitres of overnight broth culture of bacterial isolate in Luria Bertani (LB) was spun at $14000 \mathrm{rpm}$ for 3 min. The cells were re-suspended in $500 \mu$ of normal saline and heated at $95^{\circ} \mathrm{C}$ for $20 \mathrm{~min}$. The heated bacterial suspension was cooled on ice and spun for $3 \mathrm{~min}$ at 14000 rpm. The supernatant containing the DNA was moved to 1.5 $\mathrm{ml}$ micro centrifuge tube and kept at $-20^{\circ} \mathrm{C}$ for other downstream reactions.

\subsubsection{DNA Quantification}

The extracted genomic DNA was quantified using the Nanodrop 1000 spectrophotometer. The software of the equipment was launched by double clicking on the Nanodrop icon. The equipment was initialized with $2 \mu \mathrm{l}$ of sterile distilled water and blanked using normal saline. Two microlitres of the extracted DNA was loaded onto the lower pedestal, the upper pedestal was brought down to contact the extracted DNA on the lower pedestal. The DNA concentration was measured by clicking on the "measure" button.

\subsubsection{S rRNA Amplification}

The 16S rRNA region of the rRNA genes of the isolates was amplified using the 27F: 5'AGAGTTTGATCMTGGCTCAG-3' and 1492R: 5'CGGTTACCTTGTTACGACTT-3' primers on an ABI 9700 Applied Biosystems thermal cycler at a final volume of 50 microlitres for 35 cycles. The PCR mix included: the X2 Dream taq Master mix supplied by Inqaba, South Africa (taq polymerase, DNTPs, $\mathrm{MgCl}$ ), the primers at a concentration of $0.4 \mathrm{M}$ and the extracted DNA as template.

The PCR conditions were as follows: Initial denaturation, $95^{\circ} \mathrm{C}$ for 5 minutes; denaturation, $95^{\circ} \mathrm{C}$ for 30 seconds; annealing, $52^{\circ} \mathrm{C}$ for 30 seconds; extension, $72^{\circ} \mathrm{C}$ for 30 seconds for 35 cycles and final extension, $72^{\circ} \mathrm{C}$ for 5 minutes. The product was resolved on a $1 \%$ agarose gel at $120 \mathrm{~V}$ for 15 minutes and visualized on a UV transilluminator.

\subsubsection{Fungal genomic DNA extraction}

Extraction was done using a ZR fungal/bacterial DNA mini prep extraction kit supplied by Inqaba South Africa. A 
heavy growth of the pure culture of the fungal isolate was suspended in $200 \mu \mathrm{l}$ of isotonic buffer into a ZR Bashing Bead lysis tubes, $750 \mu \mathrm{l}$ of lysis solution was added to the tube. The tubes were secured in a bead beater fitted with a $2 \mathrm{ml}$ tube holder assembly and processed at maximum speed for 5 minutes. The ZR bashing bead lysis tubes were centrifuged at $10,000 \mathrm{~g}$ for 1 minute. Four hundred (400) microlitres of supernatant was transferred to a Zymo-Spin IV spin, filtered (orange top) in a collection tube and centrifuged at $7000 \mathrm{~g}$ for 1 minute. One thousand two hundred (1200) microlitres of fungal/bacterial DNA binding buffer was added to the filtrate in the collection tubes bringing the final volume to $1600 \mu \mathrm{l}, 800 \mu$ lwas then transferred to a Zymo-Spin IIC column in a collection tube and centrifuged at $10,000 \mathrm{~g}$ for 1 minute, the flow through was discarded from the collection tube. The remaining volume was transferred to the same Zymo-spin and spun. Two hundred (200) microlitres of the DNA Pre-Wash buffer was added to the Zymo-spin IIC in a new collection tube and spun at $10,000 \mathrm{~g}$ for 1 minute followed by the addition of $500 \mu \mathrm{l}$ of fungal/bacterial DNA Wash Buffer and centrifuged at 10,000 $\mathrm{g}$ for 1 minute. The Zymo-spin IIC column was transferred to a clean $1.5 \mu$ l centrifuge tube, $100 \mu \mathrm{l}$ of DNA elution buffer was added to the column matrix and centrifuged at $10,000 \mathrm{~g}$ for 30 seconds to elute the DNA. The ultra-pure DNA was then stored at $-20^{\circ} \mathrm{C}$ for other downstream reaction.

\subsubsection{Internal Transcribed Spacer (ITS) Amplification}

The regions of the rRNA genes of the fungal isolate were amplified using the ITS1F: 5'CTTGGTCATTTAGAGGAAGTAA-3' and ITS4: 5'TCCTCCGCTTATTGATATGC-3, primers on an ABI 9700 Applied Biosystems thermal cycler at a final volume of 50 microlitres for 35 cycles. The PCR mix included: the X2 Dream taq Master mix supplied by Inqaba, South Africa (taq polymerase, DNTPs, $\mathrm{MgCl}$ ), the primers at a concentration of $0.4 \mathrm{M}$ and the extracted DNA as template.

The PCR conditions were as follows: Initial denaturation, $95^{\circ} \mathrm{C}$ for 5 minutes; denaturation, $95^{\circ} \mathrm{C}$ for 30 seconds; annealing, $53^{\circ} \mathrm{C}$ for 30 seconds; extension, $72^{\circ} \mathrm{C}$ for 30 seconds for 35 cycles and final extension, $72^{\circ} \mathrm{C}$ for 5 minutes.

The product was resolved on a $1 \%$ agarose gel at $120 \mathrm{~V}$ for 15 minutes and visualized on a UV transilluminator. Sequencing were conducted using Big-Dye Terminator kit on a 3510 ABI sequencer by Inqaba Biotechnological, Pretoria South Africa. The sequencing was done at final volume of 10 $\mu \mathrm{l}$, the components included $0.25 \mu \mathrm{l}$ BigDye ${ }^{\circledR}$ terminator v1.1/v3.1, 2.25 $\mu 1$ of $5 \times$ BigDye sequencing buffer, $10 \mu \mathrm{M}$ Primer PCR primer, and 2-10ng PCR template per $100 \mathrm{bp}$. The sequencing conditions were as follows 32 cycles of $96^{\circ} \mathrm{C}$ for $10 \mathrm{~s}, 55^{\circ} \mathrm{C}$ for $5 \mathrm{~s}$ and $60^{\circ} \mathrm{C}$ for $4 \mathrm{~min}$.

\subsection{Phylogenetic Analysis}

Obtained sequences were edited using the bioinformatics algorithm Trace edit, similar sequences were downloaded from the National Center for Biotechnology Information (NCBI) data base using BLASTN. These sequences were aligned using ClustalX. The evolutionary history was inferred using the Neighbor-Joining method in MEGA 6.0 [15]. The bootstrap consensus tree inferred from 500 replicates [16] is taken to represent the evolutionary history of the taxa analyzed. The evolutionary distances were computed using the Jukes-Cantor method [17].

\subsection{Effect of Temperature on Polycaprolactone Degradation by Bacterial and Fungal Strains}

The optimum temperature for polycaprolactone degradation by bacterial and fungal strains was evaluated by growing the isolates at different temperatures from $25^{\circ} \mathrm{C}$ to $40^{\circ} \mathrm{C}$. The isolates were cultured in $100 \mathrm{ml}$ sterile mineral salt medium augmented with $5 \mathrm{~g} / \mathrm{L}$ of PCL as the only source of carbon in a $250 \mathrm{ml}$ Erlenmeyer flask. The test for each isolate was done in triplicate and $0.1 \mathrm{ml}$ of a $24 \mathrm{hr}$ culture of the isolate was added to each flask. The uninoculated control and the flasks were incubated for 15 days at different temperatures $\left(25,30,35\right.$, and $\left.40^{\circ} \mathrm{C}\right)$. Degradation of PCL was evaluated by measuring residual weight of polycaprolactone in the culture. PCL percentage degradation was calculated via the equation $[\mathrm{Wi}-\mathrm{Wx} / \mathrm{Wi}] \times$ 100 where $\mathrm{Wi}$ is weight of PCL (mg) in the uninoculated control medium and $\mathrm{Wx}$ is the weight of PCL $(\mathrm{mg})$ in the inoculated medium.

\subsection{Effect of Initial Medium pH on PCL Degradation by Bacterial and Fungal Strains}

The best medium $\mathrm{pH}$ for polycaprolactone degradation by bacterial and fungal strains was evaluated by cultivating the isolates at different medium $\mathrm{pH}$ from $\mathrm{pH} 4$ to 8 . The isolates were cultured in $100 \mathrm{ml}$ sterile mineral salt medium augmented with $5 \mathrm{~g} / \mathrm{L}$ PCL as the only source of carbon in a $250 \mathrm{ml}$ Erlenmeyer flask. The test for each isolate was carried out in triplicate and $0.1 \mathrm{ml}$ of a $24 \mathrm{hr}$ culture of the isolate was added to the flask. The uninoculated control and the flasks were incubated for 15 days at $30^{\circ} \mathrm{C}$. PCL residual weight in the culture was measured and used for PCL degradation evaluation.

\subsection{Effect of Salinity on Polycaprolactone Degradation by Bacterial and Fungal Strains}

The influence of salinity on PCL degradation by bacterial and fungal strains was evaluated by growing the isolates at different salinities $(5,10,15,20$ ppt.). The isolates were cultured in $100 \mathrm{ml}$ sterile mineral salt medium augmented with $5 \mathrm{~g} / \mathrm{L}$ PCL as the only source of carbon in a $250 \mathrm{ml}$ Erlenmeyer flask. The test for each isolate was carried out in triplicate and $0.1 \mathrm{ml}$ of a $24 \mathrm{hr}$ culture of the isolate was added to each flask. The uninoculated control flask and the flasks were incubated for 15 days sat $30^{\circ} \mathrm{C}$. PCL residual weight in the culture was measured and used for PCL degradation estimation. 


\subsection{Statistical Analysis}

Standard deviations for each of the experimental results were calculated using Excel Spreadsheets, with Microsoft excel software. Differences between treatments were examined for significance by one-way ANOVA and $P=0.05$ was considered to be statistically significant.

\section{Results and Discussion}

\subsection{PCL-Degrading Microbial Strains}

A total of three PCL- degrading bacterial strains and one PCL- degrading fungal strain identified as Alcaligenes aquatilis (Figure 1), Shewanella haliotis (Figure 2), Bacillus megaterium (Figure 3) and Filobasidium uniguttalatum (Figure 4) respectively were isolated from soil via enrichment procedure and clear zone technique. Some strains of the genera isolated in this study such as Bacillus brevis 93 [18], Bacillus pumilus I-A [19] and Shewanella sp. CT01 [20] have been implicated as bioplastic - degrading bacteria. Fusarium moniliforme Fmm [21], Paecilomyces verrucossum [22], Aspergillus sp. XH0501-a [23] and Penicillium oxalicum D SYD05- 1 [23] have been reported as bioplasticdegrading fungi.

Fifty eight isolates from agricultural soils in northern Thailand were implicated as PCL- degraders [24]. A thermophilic bacterium (Ralstonia sp. strain MRL-TL) isolated from hot spring degraded poly ( $\varepsilon$ - caprolactone) [25]. Hoang et al. [26] stated that 12 actinomycetes strains out of 305 actinomycetes isolates degraded 3 polyesters [poly 3hydroxybutyrate (PHB), polyethylene succinate (PES) and PCL]. They stated that this capability could be recognized as a result of the clear zone around the isolates as also reported in this study. This microbial degradation of bioplastics has been ascribed to enzyme biosynthesis [27]. These strains isolated in this study could have potential for use in the management of bioplastic wastes. Figure 5 shows the Phylogenetic tree showing species relatedness of isolate F1.
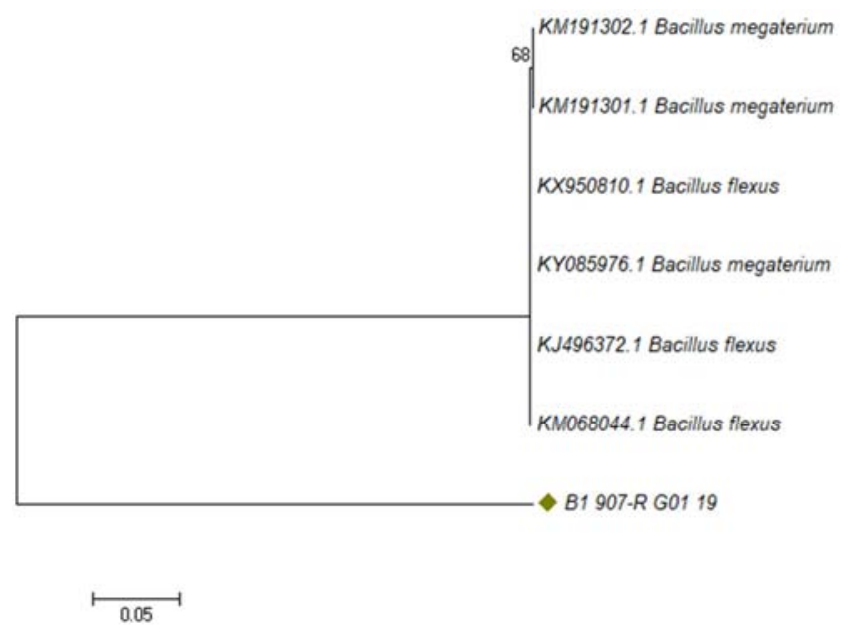

Figure 2. Phylogenetic tree showing species relatedness of isolate B1.

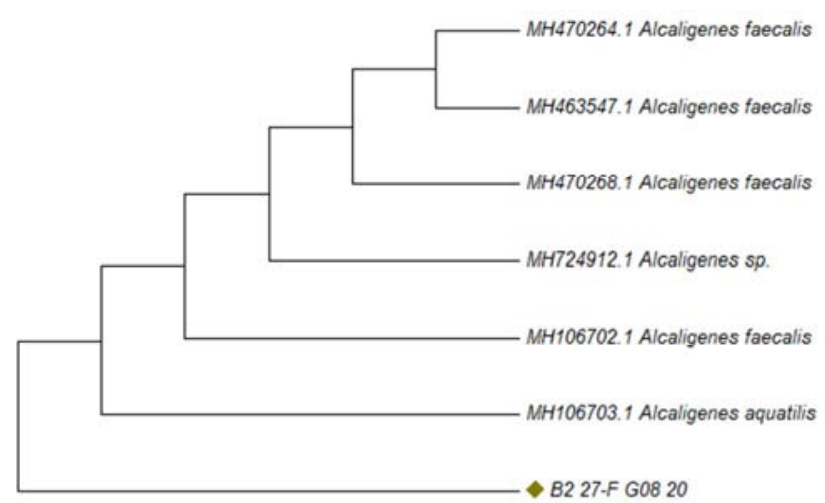

Figure 3. Phylogenetic tree showing species relatedness of isolate B2.

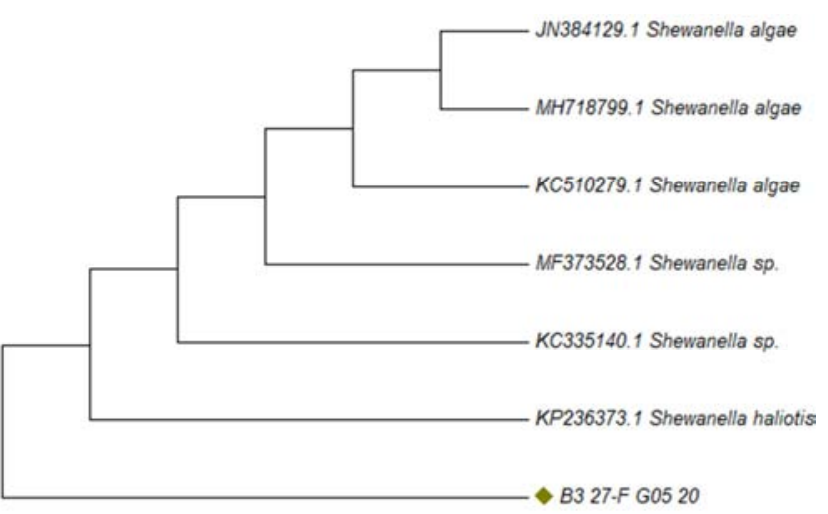

Figure 4. Phylogenetic tree showing species relatedness of isolate B3.

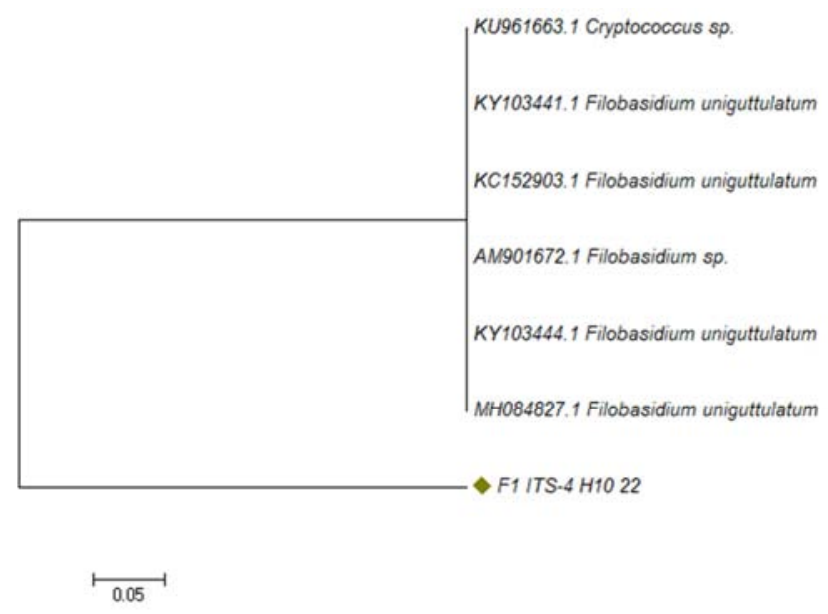

Figure 5. Phylogenetic tree showing species relatedness of isolate F1.

\subsection{Optimal Temperature for Polycaprolactone Degradation}

The effect of temperature on polycaprolactone degradation by the bacterial and fungal strains is presented in Figure 6 PCL maximum degradation rate of $59 \%$ for Bacillus megaterium, $56 \%$ for Alcaligenes aquatilis $53 \%$ for Shewanella haliotis and $62 \%$ for Filobasidium uniguttalatum were observed at $30^{\circ} \mathrm{C}$ at the end of the 15 days. There was no growth in uninoculated sterile control indicating that the detected growth in the inoculated media happened at the expense of the bioplastic. A reduction in the degradation 
efficiency was detected at temperatures below and above $30^{\circ} \mathrm{C}$. This indicates that temperature plays active role in microbial metabolism and polycaprolactone degradation. In Taiwan, Chau et al. [28] reported a bacterium (thermophilic Streptomyces thermoviolaceus subsp. thermoviolaceus 76T2) which they isolated from soil and found to degrade poly (epsilon-caprolactone) (PCL) within $6 \mathrm{hr}$. at $45^{\circ} \mathrm{C}$. Penkhrue et al. [24] stated that Amycolatopsis sp. strain SCM_MK2-4 which exhibited the maximum enzyme activity for poly lactic acid (PLA) and PCL was capable of degrading $36.7 \%$ of the PLA in a culture medium after 7 days of incubation at $30^{\circ} \mathrm{C}$. Brevibacillusagri degraded $84 \%$ of PCL originally supplemented in the medium at the end of 30 days incubation at $50^{\circ} \mathrm{C}$ (Nguyen and Trinh 2010). A thermophilic actinomycetes isolated from hot spring in Taiwan and identified as Microbispora rosea sub sp. taiwanensis fully degrade PCL, PHB and PES in liquid cultures at $50^{\circ} \mathrm{C}$ in 6 days [26].

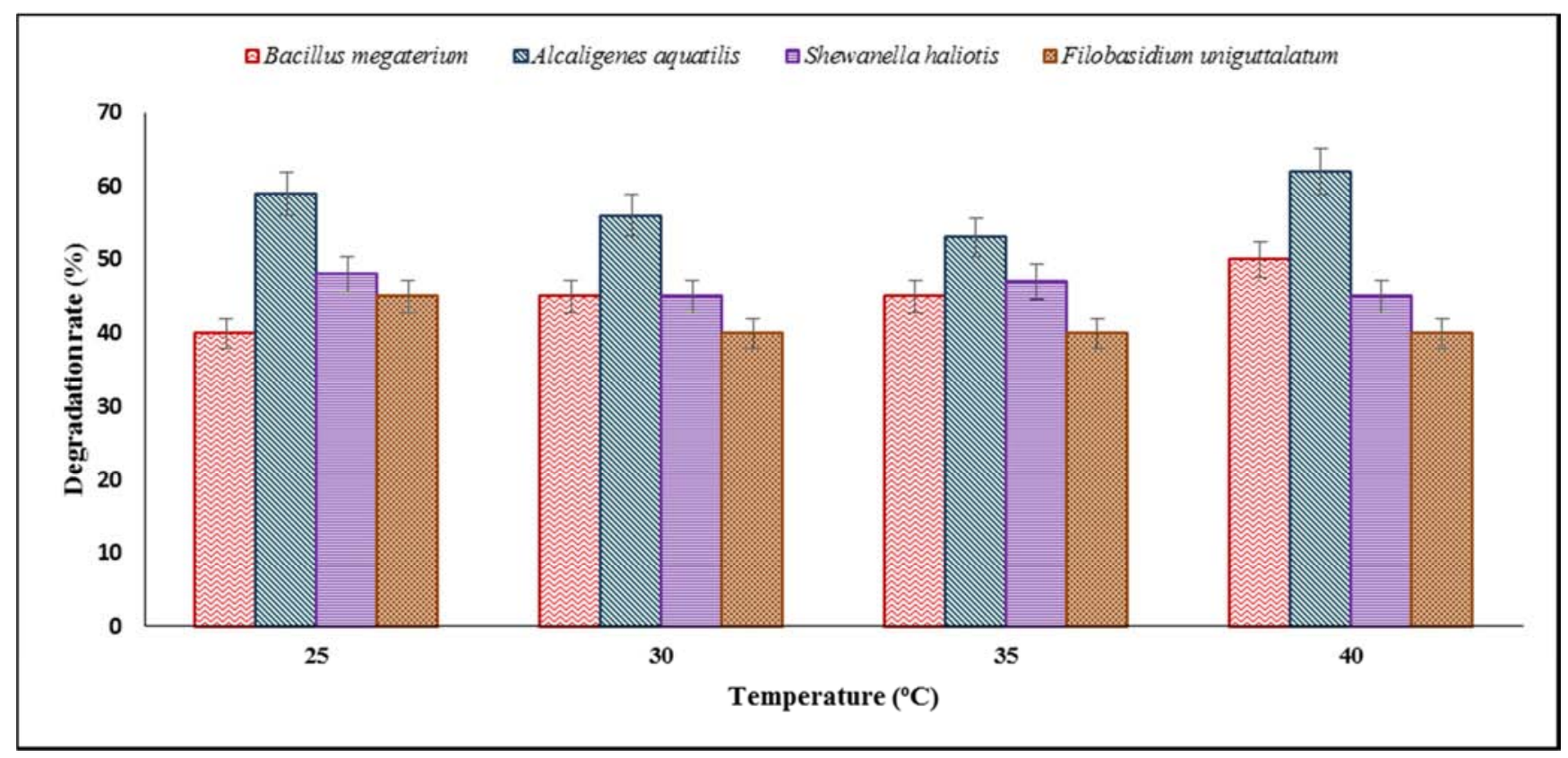

Figure 6. Effect of temperature on PCL degradation by bacterial and fungal isolates.

\subsection{Optimal Medium pH for Polycaprolactone Degradation}

The influence of medium $\mathrm{pH}$ on polycaprolactone degradation is shown in Figure 7 PCL degradation occurred at a wide range of $\mathrm{pH}$ (4-8). PCL maximum degradation rate of $63 \%$ for Filobasidium uniguttalatum was observed at $\mathrm{pH} 5$ while the maximum degradation rate of $60 \%$ for Bacillus megaterium, 54\% for Alcaligenes aquatilis and $57 \%$ for Shewanella haliotis were observed at $\mathrm{pH}$ 7. A decline in the degradation efficacy was observed for $\mathrm{pH}$ lower and higher than 7 for bacteria and $\mathrm{pH} 5$ for the fungus. The results denote that initial $\mathrm{pH}$ of culture medium affects the rate of PCL degradation. In Thailand, four polyester- degrading bacterial strains (Actinomadura sp. S14, Actinomadura sp. TF1, Streptomyces sp. APL3 and Laceyella sp. TP4) which were isolated from compost soils utilized polylactic acid (PLA), polycaprolactone (PCL), poly (butylene succinate) (PBS) and poly butylene succinate-co-adi-pate (PBSA) as substrates and exhibited robust depolymerase activity at $\mathrm{pH}$ 6.0-8.0 and temperatures of $40^{\circ} \mathrm{C}-60^{\circ} \mathrm{C}$ [30]. A PCL degrader, Brevibacillus agri, propagated well at $\mathrm{pH}$ 6-7 [31].

\subsection{Optimal Salinity for Polycaprolactone Degradation}

The effect of salinity on polycaprolactone degradation is shown in Figure 8 PCL degradation occurred at a wide range of salinity (0-20 ppt.). PCL maximum degradation rate of 58\% for Bacillus megaterium, 55\% for Alcaligenes aquatilis, $52 \%$ for Shewanella haliotis and $62 \%$ for Filobasidium uniguttalatum were detected at salinity of 5 ppt. A reduction in the degradation efficiency was detected for salinity lower and higher than 5 ppt. This demonstration that $\mathrm{NaCl}$ concentration plays active role in microbial metabolism and polycaprolactone degradation. Pseudomonas pachastrellae which grew well at $1.2 \mathrm{M} \mathrm{NaCl}$, was found to be the main bacterium that degraded PCL in coastal environs [32]. Brevibacillus agri, a PCL degrader, grew well at $1-3 \% \mathrm{NaCl}$ [31]. These observed variations in optimum conditions for PCL degradation may be due to the dissimilarities in source, nature and species of PCL degrading microbes. The variance in bioplastic degradation rates exhibited by different isolates in this study is not unexpected as diverse ecological factors are known to select for dissimilar microbial communities [33]. 


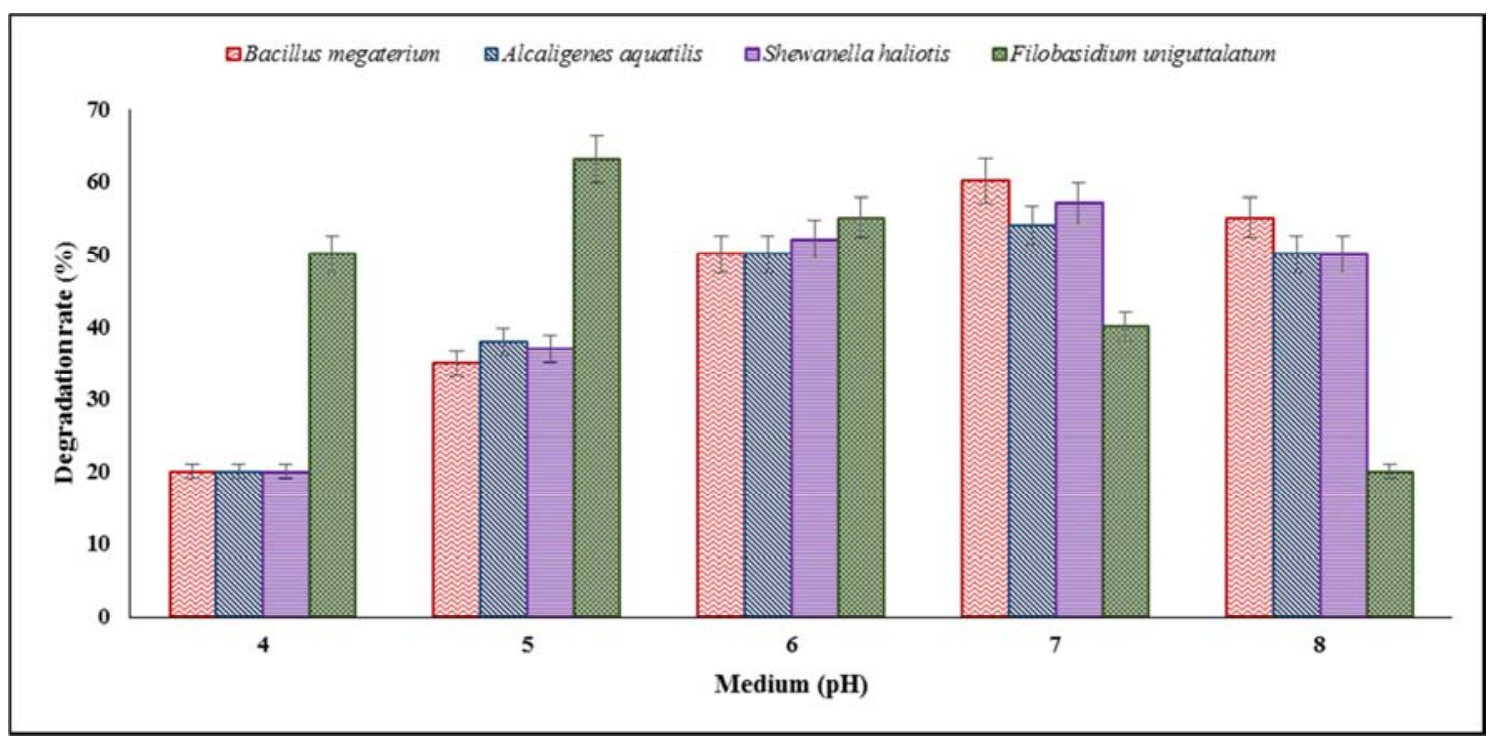

Figure 7. Effect of medium $\mathrm{pH}$ on PCL degradation by bacterial and fungal isolates.

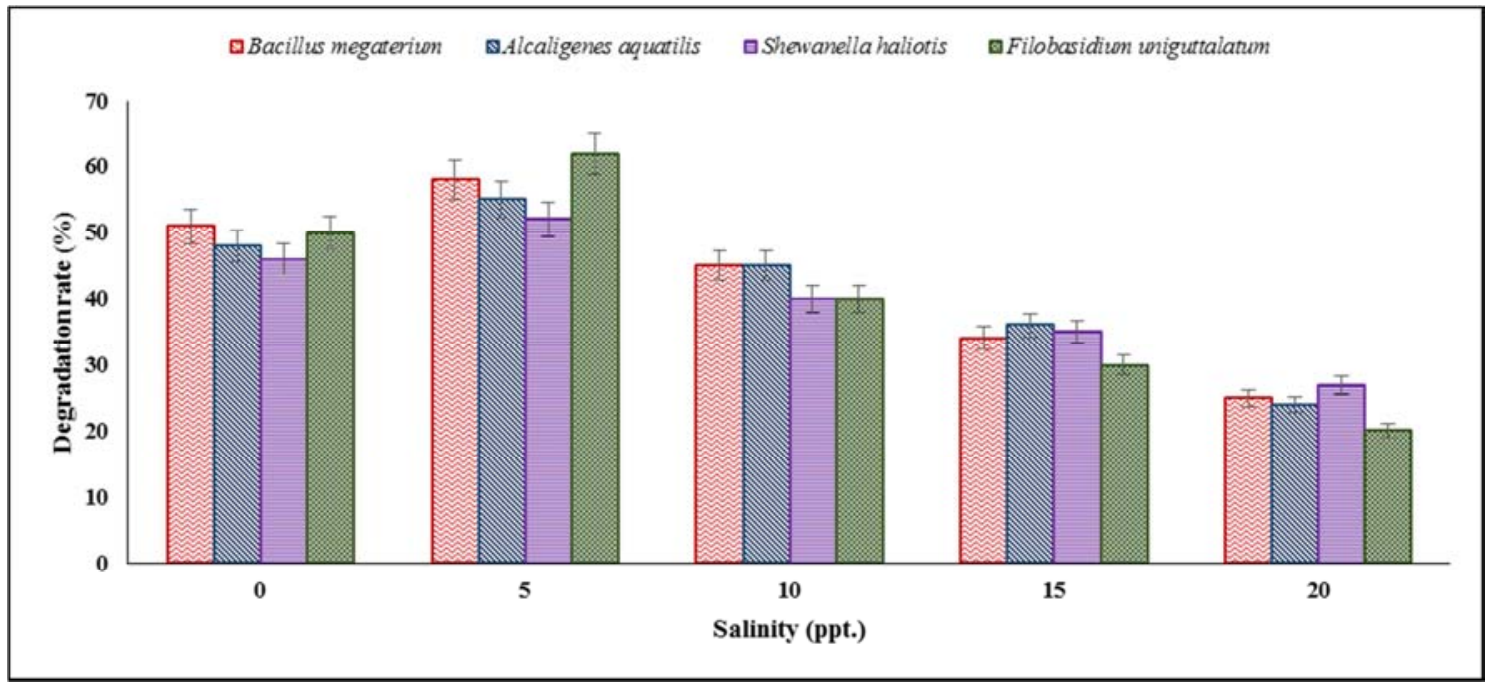

Figure 8. Effect of salinity on PCL degradation by bacterial and fungal isolates.

\section{Conclusion and Recommendation}

In this study, three new PCL degrading bacterial strains (Bacillus megaterium, Alcaligenes aquatilis and Shewanella haliotis) and one new fungal strain (Filobasidium uniguttalatum) were isolated from soil. Their degradation rates at the end of 15 days were above $50 \%$. The optimum temperature and salinity for PCL degradation were $30^{\circ} \mathrm{C}$ and 5 ppt. respectively. The maximum PCL degradation rate was observed at medium $\mathrm{pH}$ of 7 for bacterial strains and $\mathrm{pH} 5$ for the fungal strain. These microorganisms have the potential to be employed as valuable tools for enhanced management of PCL- associated ecological waste.

\section{References}

[1] Zheng Y, Yanful EK, Bassi AS (2005). A review of plastic waste biodegradation. Crit Rev Biotechnol 25: 243-250.
[2] Thompson RC, Moore CJ, vomSaal FS, Swan SH (2009). Plastics, the environment and human health: current consensus and future trends. Phil Trans R Soc B 364: 2153-2166.

[3] Hayes DG, Dharmalingam S, Wadsworth LC, Leonas KK, Miles C, Inglis DA (2012). Biodegradable agricultural mulches derived from biopolymers. In: Khemaani $\mathrm{K}$, Scholz C (eds) Degradable polymers and materials, principles and practice, 2nd edn. ACS Symposium Series, vol 1114, 2nd edn. American Chemical Society Press, Wash, DC, 201-223.

[4] Kasirajan S, Ngouajio M (2012). Polyethylene and biodegradable mulches for agricultural applications: a review. Agron Sustain Dev 32: 501-529.

[5] Tokiwa Y, Calabia BP (2006). Biodegradability and biodegradation of poly (lactide). Appl Microbiol Biotechnol 72: 244-251.

[6] Simon J, Muller H, Koch R, Muller V (1998) Requirements for biodegradable water soluble polymers. Polym Degrad Stabil 59 (1-3): 107-115. 
[7] Oda Y, Asari H, Urakami T, Tonomura K (1995). Microbial degradation of poly (3-hydroxybutyrate) and polycaprolactone by filamentous fungi. J Ferment Bioeng 80: 265-269.

[8] Oda Y, Oida N, Urakami T, Tonomura K. (1997). Polycaprolactone depolymerase produced by the bacterium Alcaligenes faecalis. FEMS Microbiol Lett 152: 339-343.

[9] Tseng M, Hoang K-C, Yang M-K, Yang S-F, Chu W (2007). Polyester-degrading thermophilic actinomycetes isolated from different environment in Taiwan. Biodegrad. 18 (5): 579-583.

[10] Nawaz A, Hasan F, Shah AA (2014). Degradation of poly ( $\varepsilon-$ caprolactone) (PCL) by a Brevundimonas sp. Strain MRLANI from soil. FEMS Microbiol Lett 362: 1-7.

[11] Ariole CN, Abubakar A (2015). Biodegradation of atrazine by bacteria isolated from lotic water. Journal of Applied Life Sciences International 2 (3): 119-125.

[12] Holt JG, Krieg NR, Sneath PHA, Stanley JT, Williams ST. (eds) (1994). Bergey's Manual of Determinative Bacteriology 9th ed. Williams and Wilkins Baltimore, Maryland, USA.

[13] Larone DH (2011) Medically important fungi: A guide to identification. 5th edition, American Society for Microbiology (ASM) Press, Washington, DC, 485.

[14] Tamura K, Stecher G, Peterson D, Filipski A, Kumar S (2013). MEGA6: molecular evolutionary genetics analysis version 6.0. Mol Biol Evol 30: 2725-2729.

[15] Saitou N, Nei M (1987). The neighbor-joining method: A new method for reconstructing phylogenetic trees. Molecular Biol. \& Evol. 4: 406-425.

[16] Felsenstein J (1985). Confidence limits on phylogenies: An approach using the bootstrap. Evolution 39: 783-791.

[17] Jukes TH, Cantor CR (1969). Evolution of protein molecules. In: Munro HN, editor, Mammalian Protein Metabolism, Academic Press, New York, 21-132.

[18] Tomita K, Kuroki Y, Nagai K (1999). Isolation of thermophiles degrading Poly (1-lactic acid). J Biosci Bioeng 87: 752-755.

[19] Hayase N, Yano H, Kudoh E, Tsutsumi C, Ushio K, Miyahara Y, Tanaka S, Nakagawa K (2004). Isolation and characterization of poly (butylene succinate-co-butylene adipate)-degrading microorganism. J Biosci Bioeng 97: 131133 .

[20] Sekiguchi T, Sato T, Enoki M, Kanehiro H, Uematsu K, Kato $C$ (2010). Isolation and characterization of biodegradable plastic degrading bacteria from deep-sea environments. JAMSTEC Rep Res Dev 11: 33-41.

[21] Torres A, Li SM, Roussos S, Vert M (1996). Screening of microorganisms for biodegradation of poly (lactic acid) and lactic acid-containing polymers. Appl Environ Microbiol 62: 2393-2397.

[22] Szumigaj J, Żakowaka Z, Klimek L, Rosicka-Kaczmarek J, Bartkowiak A (2008). Assessment of polylactide foils degradation as a result of filamentous fungi activity. Pol J Environ Stud 17: 335-341.

[23] Li F, Yu D, Lin X, Chen S (2012). Biodegradation of poly (epilon-caprolactone) (PCL) by a new Penicillium oxalicum strain D SYD 05-1. World J Microbiol Biotechnol 28: 29292935.

[24] Penkhrue W, Khanongnuch C, Masaki K, Pathom-aree W, Punyodom W, Lumyong S (2015). Isolation and screening of biopolymer-degrading microorganisms from northern Thailand. World J MicrobiolBiotechnol 31: 1431-1442.

[25] Shah AA, Nawaz A, Kanwal L, Hasan F, Khan S, Badshah M (2015). Degradation of poly ( $\varepsilon$-caprolactone) by a thermophilic bacterium Ralstonia sp. strain MRL-TL isolated from hot spring. Int Biodeter Biodegr 98: 35-42.

[26] Hoang K-C, Tseng M, Shu W-J (2007). Degradation of polyethylene succinate PES by a new thermophlic Microbispora strain. Biodegradation 18 (3): 333-342.

[27] Tokiwa Y, Calabia BP, Ugwu C, Aiba S (2009). Biodegradability of plastics. Int J MolSci 10: 3722-3742.

[28] Chua T, Tseng M, Yang M (2013). Degradation of poly ( $\varepsilon$ caprolactone) by thermophilic Streptomyces thermoviolaceus subsp. Thermoviolaceus 76T-2. AMB Express 3: 8-14.

[29] Li F, Hu X, Guo Z, Wang Z, Wang Y, Liu D, Xia H, Chen S (2011). Purification and characterization of a novel poly (butylene succinate)-degrading enzyme from Aspergillus sp. XH0501-a. World J Microbiol Biotechnol 27: 2591-2596.

[30] Sriyapai P, Chansiri K, Sriyapai T (2018). Isolation and characterization of polyester-based plastics- degrading bacteria from compost soils. Microbiology 87 (2): 290-300.

[31] Nguyen QH, Trinh TVA (2010). Degradation of polycaprolactone (PCL) at $50 \mathrm{oC}$ by a thermotolerant bacteria isolated from soil. Journal of Sciences and TechnologyVietnam National University 26: 568-574.

[32] Suzuki M, Tachibana Y, Oba K, Kasuya K-I (2018). Microbial degradation of poly ( $\varepsilon$-caprolactone) in a coastal environment. Polym Degrad Stabil 149: 1-8.

[33] Moore-Kucera J, Cox SB, Peyron M, Bailes G, Kinloch K, Karich K, Miles C, Inglis DA, Brodhagen M (2014). Native soil fungi associated with compostable plastics in three contrasting agricultural settlings. Appl Microbiol Biotechnol 98 (14): 6467-6485. 